BANCA D'ITALIA

E U R O S I S T E M A

Questioni di Economia e Finanza

(Occasional Papers)

On the response of Italian wages to the unemployment rate

by Alfonso Rosolia 

13 BANCA D'ITALIA

E U ROS I S T E M A

\section{Questioni di Economia e Finanza}

(Occasional papers)

On the response of Italian wages to the unemployment rate

by Alfonso Rosolia

Number 287 - July 2015 
The series Occasional Papers presents studies and documents on issues pertaining to the institutional tasks of the Bank of Italy and the Eurosystem. The Occasional Papers appear alongside the Working Papers series which are specifically aimed at providing original contributions to economic research.

The Occasional Papers include studies conducted within the Bank of Italy, sometimes in cooperation with the Eurosystem or other institutions. The views expressed in the studies are those of the authors and do not involve the responsibility of the institutions to which they belong.

The series is available online at www.bancaditalia.it.

ISSN $1972-6627$ (print)

ISSN 1972-6643 (online)

Printed by the Printing and Publishing Division of the Bank of Italy 


\title{
ON THE RESPONSE OF ITALIAN WAGES TO THE UNEMPLOYMENT RATE
}

\author{
by Alfonso Rosolia*
}

\begin{abstract}
In this paper I assess the responsiveness of Italian wage rates to labor market conditions and show that the specific wage measure considered has important consequences for the results. The cyclical response of wages measured by National Accounts is dampened by a number of measurement issues; on the other hand, both wage rate changes negotiated at the central level and salary items set at the firm level are found to respond more strongly to unemployment. I conclude that the observed weak response of wage measures based on National accounts does not reflect the lack of wage flexibility but rather the staggered and uncoordinated nature of wage negotiations.
\end{abstract}

Classificazione JEL: E24, J01, J31, J5.

Keywords: unemployment, wages, centralised wage bargaining.

\section{Contents}

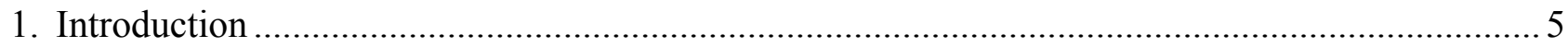

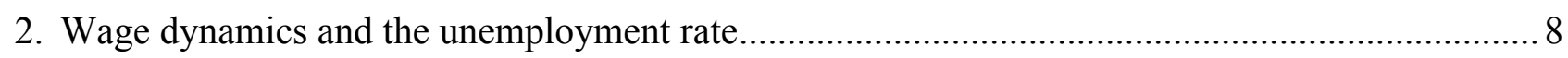

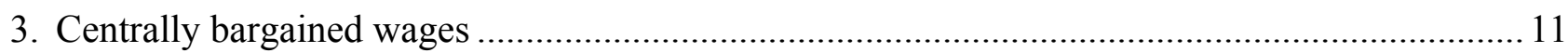

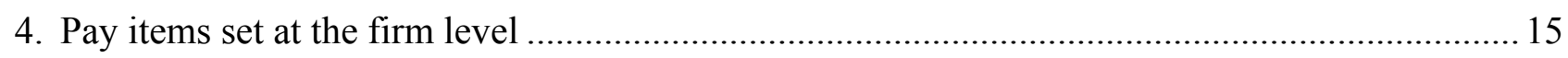

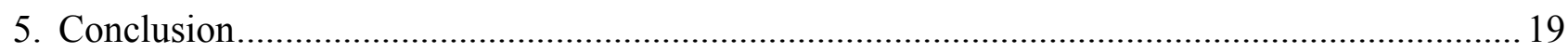

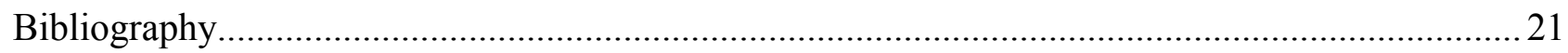

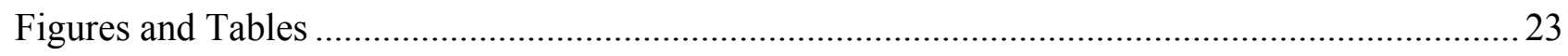

* Banca d'Italia, Directorate General for Economics, Statistics and Research. The usual disclaimer applies. 



\section{Introduction}

Unemployment increased sharply in the aftermath of the 2008 global recession; five years on it remains high in most advanced economies. For many countries, wage rigidities are seen as one of the underlying causes for the low resilience of the labour market against sizeable adverse macroeconomic shock. In the euro area, wage flexibility is often seen as a way to restore relative cost developments among countries bound by a common monetary policy, thus absorbing internal imbalances. (e.g. European Central Bank (2012b), OECD (2012)).

In this note I assess the degree of response of Italian wages to labour market developments paying particular attention at the wage structure. As explaiend below, the commonly used wage rate computed from the National Accounts is a synthesis of many different factors whose dynamics may obscure the degree and source of adjustment of wages to cyclical developments, potentially leading to incorrect policy advice.

First, employee compensations include items, such as arrears and other one-off payments, which, although not generally linked to cyclical developments, can determine sizeable swings in NA wage rates. For example, the excess growth observed in 2008 in Italy largely reflected oneoff payments to compensate for unusually long delays in the renewal of several major collective contracts. Moreover, short-run NA compensation dynamics may reflect action on the intensive margin of employment (e.g. extra-hours, work-sharing schemes) unmeasured by conventional labour input measures.

Second, important composition effects may stem from a changing workforce over the cycle. The European Central Bank (2012a) estimates that in the majority of euro area countries the contraction in the share of lowest-paying jobs held by those worst hit by the crisis (the 
young, those with fixed-term contracts, manufacturing and construction workers, and lowskilled workers) mitigated or even offset the contraction in wages at constant composition (price effect). In Italy, net of these composition effects, real wages for male workers would have declined by an average 2.3 percent between 2008 and 2010, those for female workers by 1.9 percent against recorded rates of -0.6 percent and 0.9 percent, respectively. D'Amuri (2014), exploiting a more detailed breakdown of the Italian labour force, finds that between 2009 and 2013 about 40 percent of the rise in gross nominal hourly wages (net of items paid intermittently, such as bonuses and occasional overtime) can be traced to composition effects.

Finally, wage determination follows from multiple negotiation layers and is staggered by nature, so that even significant responses to labor market conditions may show up only weakly in the NA aggregate wage measures. Since the early 90s wage bargaining in Italy takes place at two complementary levels 1 . Multi-year contracts negotiated at the central level by sectoral employers' associations and trade unions set both basic pay levels and the rules governing the employment relationship for broad sectors of activity and firm sizes with the aim of preserving wages' purchasing power and setting minimal working standards. Until 2009, contracts lasted 2 years for economic provisions and 4 years for normative ones; since then the duration has been set at 3 years for all matters2 2 . Agreements negotiated at the firm or local level area aimed at tailoring labour costs, incentive structures and labour organization to the firm needs and local circumstances and, ultimately, redistribute productivity gains. However, such contracts cannot generally undo normative provisions nor lower wages below those centrally set. Only

\footnotetext{
${ }^{1}$ The structure of idnustrial relations is set autonomously by the social partners through periodi agreements that set the rules and content of the various bargaining levels; Government involvment is shaping such protocols is very limited. See Ichino (2004) for a review of recent developments in industrial relations in Italy.

${ }^{2}$ See the social agreement signed in 2009 by most employers assocications and trade unions. See Visco (2008) for a critical discussion of the new bargaining setting
} 
recently, social parties have expanded the reach of such contracts allowing some margins to modify centrally established normative and economic provisions (D'Amuri and Giorgiantionio (2013))

Within this setting, abstracting from measurement and composition issues, lack of significant adjustment of NA wages might either reflect a high degree of insulation of wage setting institutions from labour market conditions, perhaps because of strong insiders' power, or an excessive staggering of contracts. Policy advice to improve flexibility should of course be different in the two cases.

To address the role of the different negotiation layers in shaping wage flexibility, in the paper I examine the response to current labour market conditions of several wage measures, set at different levels. Specifically, I focus on nominal wage changes (a) as measured by the National Accounts (sect. 2), (b) as agreed upon renewals of national collective agreements (sect. 3), (c) as determined by firm-level contracts and pay strategies (sect. 4). I look at the relationship between such measures and labour market developments through the lenses of a wage Phillips curve (WPC). A reconciliation of the empirical wage Phillips-curve relationship with economic theory is not straightforward. Most models imply a wage curve, that is a negative relationship between the level of the real wage and unemployment. Borrowing from Blanchard and Katz (1999), "[...] Almost all theoretical models of wage-setting generate a strong core implication: the tigther the labour market, the higher is the real wage [...]"; they show that the two relationships can be reconciled under quite restrictive and ad hoc, though realistic, assumptions on the effects of productivity on wages given the reservation wage and on the reservation wage itself, however. Sestito (1994) reviews, discussing the Phillips-curve and the wage equation approaches, the available empirical evidence for Italy. More recently, 
Galí (2011) has shown instead that a standard Phillips-curve relating nominal wage changes and unemployment arises naturally in standard New Keynesian models with staggered wage setting and a meaningful definition of unemployment, its slope a function of the degree of wage staggering and the elasticities of labour supply and demand ${ }^{3}$.

Results show that, while the overall correlation of NA wage changes with current unemployment rate is pretty weak, centrally bargained wages respond quite sizeably to short-run labor market developments and such responsiveness appears to have increased in the EMU years. As concerns wage items set at the firm-level, I find that higher local unemployment is associated to a lower likelihood of pay rises on top of those established by nationally bargained contracts; moreover, the value of wage items set at this bargaining level turns out to be lower the higher the local unemployment rate. While a large fraction of such response happens among firms that keep paying a positive premium, I also find that the share of firms not topping up at all the centrally set wage increases with local unemployment, suggesting some degree of downward wage rigidity.

\section{Wage dynamics and the unemployment rate}

Figure (1) displays a standard Phillips-curve relationship for Italy. I plot yearly percentage change of NA nominal wages per full-time equivalent in the private sector against the unemployment rate over the period 1970-2012. Several phases are evident, not always consistent with a negative relationship: the sharp rise of nominal wages in the 70s against subdued un-

\footnotetext{
${ }^{3}$ Until recently, most of the recent macroeconomic literature has focussed instead on the relationship between price inflation and measures of cyclical slack, of which unemployment is one, referring to it as Phillips-curve. Recent developments in the New Keynesian literature have brought back at the forefront of the debate the wage-block of the model. See Riggi (2010) for a critical review of the role played by the labour market in such models.
} 
employment increases, the fast disinflation of the 80s and early 90 s together with quickly rising unemployment rates also ensuing the EMS crisis, the achievement of low nominal wage growth rates since the onset of the EMU and declining unemployment rates, and finally the crisis years with almost doubling unemployment rates against still moderate wage pressures. Most of the disinflation of the '80s, mostly determined by explicit policy measures, and by the wage moderation introduced first by eliminating wage indexation in the mid ' 80 s and then by explicitly targeting wage renewals to the Government target inflation rate after the Income policy agreements of the early '90s. Figure (2) shows the same data at quarterly frequencies in a time series fashion and together with consumer price inflation highlighting the recessions over the entire period; the sheer scale of the graphs suggests that the negative relationship has waned in the recent decade; however, as figure (3) shows, while greatly dampenend, it appears still in place.

In table (1) I report estimates of the wage inflation-unemployment relationship 5 . Throughout I relate the wage change between quarters $t$ and $t+4$ to the the unemployment rate as measured at quarter $t$. Column (1) confirms the visual impression from the previous figures that wage inflation is strongly negatively correlated with the initial unemployment rate over the entire period 1970-2012; the coefficient suggests that each additional point of unemployment is

\footnotetext{
${ }^{4}$ Gressani, Guiso and Visco (1994) offer a quantitative assessment of the role played by several international exogenous developments and national endogenous policy responses in sustaining the strong disinflation of the '80s; Brandolini, Casadio, Cipollone, Magnani, Rosolia and Torrini (2007) discuss the role of the Income policy agreements of 1992-93; Fabiani, Locarno, Oneto and Sestito (1998) find that the lower responsiveness of nominal wages due to such agreements has increased the overall resilience of national prices to shocks and the variability of real wages, making the pre-EMU Italian monetary policy more effective.

${ }^{5}$ Throughout I neglect the important issue of the deep regional divides that charatterize the Italian economy. As concerns the issue at stake, much work has been devoted to understanding whether wage dynamics indeed respond only to the labour market conditions of the northern, more developped, regions and what are the consequences for the working of the Italian labour market, in particular with respect to the Southern regions. See, for example, Bodo and Sestito (1989), Casavola, Gavosto and Sestito (1995), Bodo and Visco (1987), Brunello, Lupi and Ordine (2000).
} 
associated with a 2 points lower wage inflation over the subsequent year. Column (2) considers also past consumer price inflation, measured between $t-4$ and $t$; such extension reduces by a half the coefficient on unemployment while the coefficient on price inflation is positive and the restriction of it being unity cannot be rejected with 1 percent confidence level. In column (3) I consider a measure of households' expected unemployment developments, which should capture the forward-looking nature of the wage setting process. It turns out positive and statistically significant but such significance vanishes when it is considered together with past consumer inflation (col. (4)). The forward-looking nature of the wage setting process implies that also price inflation expectations play a role. I thus add a measure of expected inflation over the next year obtained from Consensus forecasts. As it is available only since 1989 in column (5) I restimate the model of column (4) with unemployment rate, past price inflation and expected unemployment change over the period 1989-2012. Over this period, labour market developments as measured by current unemployment rate and expected unemployment changes turn out not to be significantly correlated with wage inflation. Explicit consideration of price inflation expectations only restores statistical significance of expected unemployment developments (col. (6)): a ten percentage points increase in the proportion of households expecting increased unemployment is associated with one fourth of a point slower nominal wages. Holding price expectations constant, past price inflation enters negatively, while expected price inflation has a strong amplification effect of wage dynamics.

In columns (7) to (11) I limit the sample to 1998-2012, the EMU period, and rerun the previous specifications. Current unemployment rates are never correlated in a significat way with wage inflation, while expected unemployment dynamics appear to be only weakly correlated. Only past and expected price inflation correlate significantly with wage inflation, with a strong 
negative effect of past inflation and a high, though less precisely estimated than on the entire sample, positive effect of expected price developments.

All in all, the evidence based on National accoutns wage measures suggests that the Philipscurve has disappeared since the late '90s, with nominal wage dynamics reflecting little or not at all developments in the labour market.

Is this evidence that wage setting mechanisms are insulated from the business cycle? If so, why? The next sections study more in detail the two main bargaining levels in Italy and their responsiveness to developments in the labour market.

\section{Centrally bargained wages}

In this section I study the response of centrally bargained wages to labour market developments. I construct a panel of 20 sectoral agreements covering both industry and private services whose renewals are observed since the early 90s. For each renewal I have information on the date, delay with respect to the expiration of the previous contract, initial wage levels, the overall pay rise and the timing of the installments. This information improves on commonly available indexes of negotiated wages which, though often available at monthly frequencies, do not allow to recover the precise bargained wage increase and how it is spread over the contract life. Variation in such indexes may thus capture changes that have been agreed much before the date they actually occur. The typical centrally bargained contract sets a total wage increase, that is what will be the new wage level at contract expiration, and the timing of the payments that gradually

lead to that level over the contract life. As an example, figure (4) displays such features for 2 specific renewals and four main contracts. The lines represent the proportion of the negotiated 
wage increase paid in each month. It is clear how the timing of the instalments for a given negotiated wage increase can make a substantial difference in the evolution of labour cost over the contractual span. Monthly indexes that are uninformative on such features would give a wrong assessment of the relationship between bargained wages and labour market codnitions.

To fully explit the informaton collected I focus on two measures of negotiated wage increase: the (annualised) increase as measured by the ratio of the wage level at expiration of the renewed contract, after all installments will have been paid out, to the initial wage level $\left(\Delta^{X}\right)$ and the average wage increase recorded in the year after renewal $\left(\Delta^{1}\right)$ which only accounts for the cumulated flow of payments made in the 12 months following renewal.

Specifically, let $w_{0}$ the initial wage rate and $i_{s 0}{ }^{D}$ the sequence of monthly installments agreed upon, with $D$ the duration of the contract; the wage level at a given moment $t$ between renewal and expiration is $w_{t}=w_{0}+\sum_{1}^{t} i_{s}$. Therefore, the two measures I consider for each renewal are:

$$
\Delta^{X}=\left(w^{D}-w_{0}\right) / w_{0}=\sum_{1}^{D} i_{s} / w_{0}
$$

and

$$
\Delta^{1}=\left(\sum_{s=1}^{12} i_{s}(13-s) / 12\right) / w_{0}
$$

Therefore, $\Delta^{X}$, the final wage change which will be the reference for the next round of negotiations, and $\Delta^{1}$ the average increase of the wage rate during the first year after renewal, can be set somewhat independently by chosing the appropriate sequence of installments thus providing a furher bargaining margin to adjust to macroeconomic developments 6 .

Figure (5) depicts the evolution of negotiated pay rises, wage changes as measured by the NAs and the unemployment rate. The sharp decline in nominal developments in the second half of

\footnotetext{
${ }^{6}$ Note that, since payments are normally spread over the contractual horizon, high frequency variations of commonly used negotiated wage indexes are little informative on the way wages are responding to a changing economic outlook as they embed also payments agreed upon in prior periods.
} 
the 90 s is the consequence of the new bargaining setting and the adoption of a government set target inflation rate in contract renewals. Wage developments measured by National accounts track loosely negotiated wage developments and the unemployment rate 7 .

Figure (6) plots a nominal and a real Phillips curve based on negotiated wages. On the left hand side, it displays $\Delta^{X}$, that is the (annualised) overall nominal wage change implied by the agreement, and, on the right and side the expected real change obtained adjusting $\Delta^{X}$ with current Consensus inflation forecasts, against the unemployment rate at renewal dates. Comparing the two figures it is clear that a large portion of the variability characterising renewals in 90s reflect the quickly changing equilibrium inflation rate.

Table (2) reports estimates based on negotiated wages; the models are as close as possible to those estimated in table (1) on quarterly National accounts data ${ }^{8}$.

In column (1) I regress the overall annualised bargained wage change from all contract renewals collected since 1991 on unemployment rate at renewal and obtain a small negative non-statistically significant coefficient. The lack of statistical significance is confirmed when adding contract FE to account for differences across sectors (col. (2)). In columns (3) to (5) I include a measure of past consumer price inflation and of expected unemployment developments, of which only the former enters significantly with a coefficient higher than one; the hypothesis of it being unity cannot be rejected at cuustomary confidence levels; unemployment rate at renewal gains significance, implying that one additional point slows down negotiated yearly wage growth by nearly two tenth of a percentage points. Accounting explicitly for

\footnotetext{
${ }^{7}$ Recall that negotiated wages account for only about 80 percent of NAs wages, the difference being due, among others, to employment composition, pay items set at lower bargaining levels, extra hours.

${ }^{8}$ Importantly, the cross-sectional variability provided by the data used in this and subsequent section allows a somewhat more careful assessment of the Phillips-curve as it allows to control for a number of potentially confounding aggregate factors that make the estimation of such relationships on aggregate data fraught with difficulties. See Gaiotti (2010) for an assessment of the price Phillips-curve on Italian firm-level data.
} 
expected price inflation (col. (6)) considerably weakens the correlation of wage changes with current unemployment rate but restores the role of expected unemployment developments; the sign on past consumer inflation becomes negative and that on expected inflation is positive. The sum of the two cannot be rejected to be zero. The evidence thus suggests that overall negotiated wages respond to current and expected labour market developments. To explore the adjustment margins offered by the possibility of setting the timing of payments for a given overall negotiated wage increase, in column (7) I use as dependent variable the average wage increase over the first year after renewal $\left(\Delta^{1}\right.$ defined above) controlling for the negotiated pay rise. Current unemployment enters significantly and with an almost threefold coeffcient if compared with column (6); of the remaining explanatory variables, only the total wage increase remains statistically significant.

Finally, in columns (8) to (11) I limit the sample to the EMU period. The simple correlations of current unemployment with overall negotiated wage increases is much higher than that estimated for the total sample of renewals (col. (8)), even accounting for contract FEs (col. (9)). Considering past and expected price inflation and expected unemployment, the coefficient on current unemployment is reduced, although still significant and larger, in absolute values, that that estimated for the entire sample (col. (10)). Considering also the significant response to expected unemployment developments, labour market conditions appear to shape negotiated wage changes in a significant way over the EMU period, more strongly than before. Also, the response of the average first year increase (col. 11) to current unemployment is larger in the EMU than on average. Interestingly, while in the entire sample the overall negotiated wage increase is strongly correlated with the average first year increase (col. (7)), in the EMU years such correlation is substantially weakened and non statistically significant, suggesting that the 
timing of payments has gained some relevance as a tool to adjust wage developments.

The evidence reported above shows that centrally bargained wages respond to unemployment developments. The degree of response appears, especially in the EMU years, to be significantly higher than that detectable from similar specifications estimated on National accounts wage measures.

\section{Pay items set at the firm level}

In this section I study the degree to which labour-market conditions affect wage items set at the firm-level, through either explicit firm-level contracts or items unilaterally set by the employer. As discussed in the Introduction, such items are typically in addition to those set at the central level.

I use the yearly Survey of manufacturing and non-financial services firms run by the Bank of Italy. Since 1995 firms are asked whether, in a given year, wage increases higher than those implied by the reference national contract have been paid 9 . While no information is available on the amount of such additional increases and on the relevant national contract, the information allows to estimate a qualitative Phillips-curve relationship in which the dependent variable is an indicator of whether the firm increased the centrally established pay rise. Figure (7) reports the percentage of firms answering positively computed on the total sample, which over time has been expanded to cover also services and 20-49 firms, and on the subsample of manufacturing firms with at least 50 workers. The likelihood of additional pay rises displays some cyclicality, increasing strongly in the late 90s, dropping afterwards diring the early 2000 recession and

\footnotetext{
${ }^{9}$ This question is asked in a special module usually run in the autumn to update firms' forecasts on onw and aggregate developments.
} 
picking up again just before the onset of the current recession.

Figure (8) makes even more clear the significant correlation between the chances that wages increase beyond the rate established by the national contract and local labor market conditions. It plots the region-year unemployment rate against the proportion of firms in the region-year that grant additional pay rises for the 20 italian regions and since 1995. As column (1) in table (3) shows, such correlation is statistically significant and implies that a 1 percentage point increase of the local unemployment rate reduces by 2 percentage points the probability that additional pay items are paid out by the firm. Column (2) shows that the short unemployment rate plays a more relevant role in shaping such probability than the long unemployment rate. Not surprisingly, the correlation becomes weaker, while still statistically significant, once sector-area-size specific dummies (col. (3)) and year dummies (col. (4)) are included, which implies that variation due to common shocks is washed out. In the remaining columns (5)-(7) I consider firm-specific conditions by adding self-reported qualitative assessments of expected profits and own demand developments. The expectation of positive profits and positive demand developments increases the chances of additional pay rises. The results are robust to the inclusion of region-dummies along all other controls (col. (6)) and to the substitution of year dummies and sector-size-area dummies with sector-size-area specific year dummies (col. (7)). This latter demanding specification still yields a negative and statistically significant correlation with the short unemployment rate and confirms the reasonable association of additional pay rises with positive developments at the firm level for given background developments captured by the region dummies and the sector-size-area specific year dummies.

I conclude that the empirical evidence is consistent with a qualitative Phillips-curve relationship, whereby the likelihood of pay rise beyond those the firm is bound to by the centrally 
bargained contract decreases with higher local unemployment.

Yet, this evidence is silent about the economic magnitude of such additional pay items. To quantify the role of wage items not imposed by national contracts I resort to another information collected since 2002 by the Bank of Italy's survey on firms, namely the percentage of own average labor costs established by the reference national agreements. In figure (9) I plot the year-region average percentage of labor costs not set by national contracts against the regional unemployment rate. Again, the negative correlation is pretty evident. The associated regression analysis on firm-level data, reported in table (4), confirm the visual impression. A simple regression of the weight of firm-set wage items on total labour cost on current regional unemployment rate suggests that an additional percentage point of local unemployment reduced the incidence of firm-set items by 0.7 percentage points (col. (1)). From column (2) onwards I add year dummies for sector-area-size groups thus flexibly capturing cyclical developments. Columns (2) and (3) estimate a coefficient of -0.3 , which resists inclusion of firm-level controls (col. (3)). Finally, in column (4) I split the unemployment rate into the short and long duration rates; again, the short unemployment seems to put stronger pressure on firm-set wage items: an additional percentage point cuts the share of firm-set wage items by almost one percentage point. Because of the inclusion of sector-area-size-year specific dummies, the variation in the share of locally-set wage items is presumably unaffected by the response of centrally bargained wages to aggregate unemployment discussed in the previous section. In this sense, the coefficient on unemployment rate can be safely read as the change in incidence due only to changes in the value of firm-set items when centrally bargained wages are held constant, thus the percentage change in average labor cost due to increased local unemployment. To further support this reading of the results, in column (5) I augment the specification of column (4) with the (log 
of) average labor cost set by the relevant national contract. The effects of short and long unemployment rates is substantially unaffected while a one percentage point higher centrallyset average wage implies a one-tenth of a point lower share of firm-set wage items.

Such results show that, on average, higher local unemployment is associated with a lower weight of wage items set at the firm-level. However, such average result could be due both to firms lowering such share while keeping it constant and to firms going all the way to zero. The relative weight of the two choices could provide a hint about the binding role of centrally negotiated wages in local wage adjustments. To explore the issue, I proceed in steps. First, I reestimate the specification of column (5) restricting the sample to firms reporting a strictly positive weight of firm-set wage items (col. (6)), that is about two thirds of the initial population. The results are broadly unchanged, suggesting that a large part of the average response comes from unconstrained firms. In particular, the correlation with short-term unemployment is somewhat weaker, implyng that an additional point of unemployment reduces the incidence of firm-set wage items by 0.8 points, and long-term unemployment is now not significant. Interestingly, labour turnover is associated with a larger drop in the share of firm pay. To assess how much of the average decline estimated in column (5) reflects an increase in the share of firms reporting no wage items locally set, in column (7) I use as dependent variable a dummy for firms reporting zero firm-set wage items. A one-percentage point higher unemployment rate is associated with 5.6 percent more firms not topping up the centrally set wage. On average, about 30 percent of firms report no topping up of the centrally bargained wage, therefore the change induced by unemployment rate fluctuations is sizeable, suggesting that labour cost is subject to some degree of downward rigidity. 


\section{Conclusions}

I have explored whether Phillips-curve relationships between wage inflation and unemployment are detectable in the Italian labour market, to assess the degree to which wages respond to labour market developments.

I have shown that the specific wage measure considered has important consequences for the results. National accounts measures are affected by a number of measurement issues which likely dampen its response to cyclical developments. A cleaner measure of the change in wage rates is obtained looking at centrally bargained contract renewals. Estimates of standard Phillips-curve relationships on such data yield a response to the unemployment rate much stronger than the negligible one observed in National accounts over the recent decade. This suggests that, per se, even in Italy centralised bargaining is not a source of wage adjustment rigidity (Blanchard, Jaumotte and Loungani (2014)). To the extent that its staggered nature slows the global response of wages, however, a shorter duration of nationally negotiated labour contracts and higher coordination of renewals might improve the responsiveness of wages to macro shocks. Yet, this change should be weighed against the higher costs of more frequent negotiations.

I have then explored the extent to which firm-level bargaining responds to the economic cycle. Again, the evidence points to significant responses of firm-level components of labour cost to labour market developments, even under the constraints imposed by centrally bargained wages.

Are these responses sufficient? To answer this question one would need a clear benchmark in terms of welfare. And still, the answer would depend on many details. Galí (2013) and Galí and Monacelli (2013) show that within a New Keynesian framework characterised by nominal rigidities in price and wage setting, the optimal degree of wage flexibility depends on features 
such as the degree of price rigidity (and hence the regulatory framework of goods and service markets), the kind of monetary policy run by the monetary authority, the degree of openness of the economy. Perhaps more importantly, they show that more wage flexibility does not always carry welfare gains. 


\section{References}

Blanchard, Olivier and Lawrence F. Katz, "Wage Dynamics: Reconciling Theory and Evidence," American Economic Association: Papers and Proceedings, 1999.

—, Florence Jaumotte, and Prakash Loungani, "Labour Market Policies and IMF Advice in Advanced Economies During the Great Recession," IZA Journal of Labor Policy, 2014.

Bodo, Giorgio and Ignazio Visco, "La Disoccupazione in Italia: un'Analisi con il Modello Econometrico della Banca d'Italia," 1987. Bank of Italy, Discussion paper n. 91.

- and Paolo Sestito, "Disoccupazione e Dualismo Territoriale," 1989. Bank of Italy, Discussion paper n. 123.

Brandolini, Andrea, Piero Casadio, Piero Cipollone, Marco Magnani, Alfonso Rosolia, and Roberto Torrini, "Employment Growth in Italy in the 1990s: Institutional Arrangements and Market Forces," in Nicola Acocella and Riccardo Leoni, eds., Social Pacts, Employment and Growth, Physica-Verlag, 2007, chapter 3.

Brunello, Giorgio, Claudio Lupi, and Patrizia Ordine, "Regional Disparities and the Italian NAIRU," Oxford Economic Papers, 2000, 52.

Casavola, Paola, Andrea Gavosto, and Paolo Sestito, "Salari e Mercato del Lavoro Locale," Lavoro e Relazione Industriali, 1995, 4.

D’Amuri, Francesco, "Composition effects and wage dynamics in Italy," 2014. mimeo, Bank of Italy.

- and Cristina Giorgiantionio, "Dall'Accordo di Pomigliano all'Intesa sulla Rappresentanza: Stato dell'Arte e Prospettive della Contrattazione Collettiva Aziendale in Italia," 2013. mimeo, Bank of Italy.

European Central Bank, 2012 Structural Issues Report: Euro Area Labour Markets and the Crisis, Task Force of the Monetary Policy Committee of the European System of Central Banks, 2012.

- Monthly Bullettin August 2012.

Fabiani, Silvia, Alberto Locarno, Giampaolo Oneto, and Paolo Sestito, "Results and Problems of Five Years of Incomes Policy: an Initial Quantitative Evaluation," 1998. Bank of Italy, Discussion paper n. 329.

Gaiotti, Eugenio, "Has Globalization Changed the Phillips Curve? Firm-Level Evidence on the Effect of Activity on Prices ?," International Journal of Central Banking, 2010, 6 (1), 51-84.

Galí, Jordi, "The Return of the Wage Phillips Curve," Journal of the European Economic Association, 2011, 9 (3), 436-461.

- , "Notes for a New Guide to Keynes (I): Wages, Aggregate Demand, and Unemployment," Journal of the European Economic Association, 2013, 11 (5), 973-1003.

- and Tommaso Monacelli, "Understanding the Gains from Wage Flexibility: The Exchange Rate Connection," 2013. CREI, Barcelona, mimeo.

Gressani, Daniele, Luigi Guiso, and Ignazio Visco, "Disinflation in Italy: an analysis with the econometric model of the Bank of Italy," in M. Baldassarri, ed., The Italian economy: heaven or hell?, New York: St. Martins Press, 1994, pp. 111-155.

Ichino, Pietro, "Breve Storia della Contrattazione Articolata," 2004. LaVoce.info, http://archivio.lavoce.info/articoli. 
OECD, OECD Employment Outlook 2012, OECD Publishing, 2012.

Riggi, Marianna, "Nominal and Real Wage Rigidities in New Keynesian Models: a Critical Survey," Journal of Economic Surveys, 2010, 24 (3), 539-572.

Sestito, Paolo, "Determianzione del Salario in Italia: una Rassegna della Letteratura Empirica , un'Analisi della Letteratura Macro," in C. Dell'Aringa, ed., La Determinazione dei Salari: Teoria ed Evidenza Empirica, Economia del lavoro, Napoli: Edizioni Scientifiche Italiane, 1994.

Visco, Ignazio, "Indagine Conoscitiva sull'Assetto delle Relazioni Industriali e sulle Prospettive di Riforma della Contrattazione Collettiva," 2008. Testimony at the XI Commission (Public and private employment), Chamber of Deputies, Italian Parliament. 
Figure 1: The Italian wage Phillips curve.

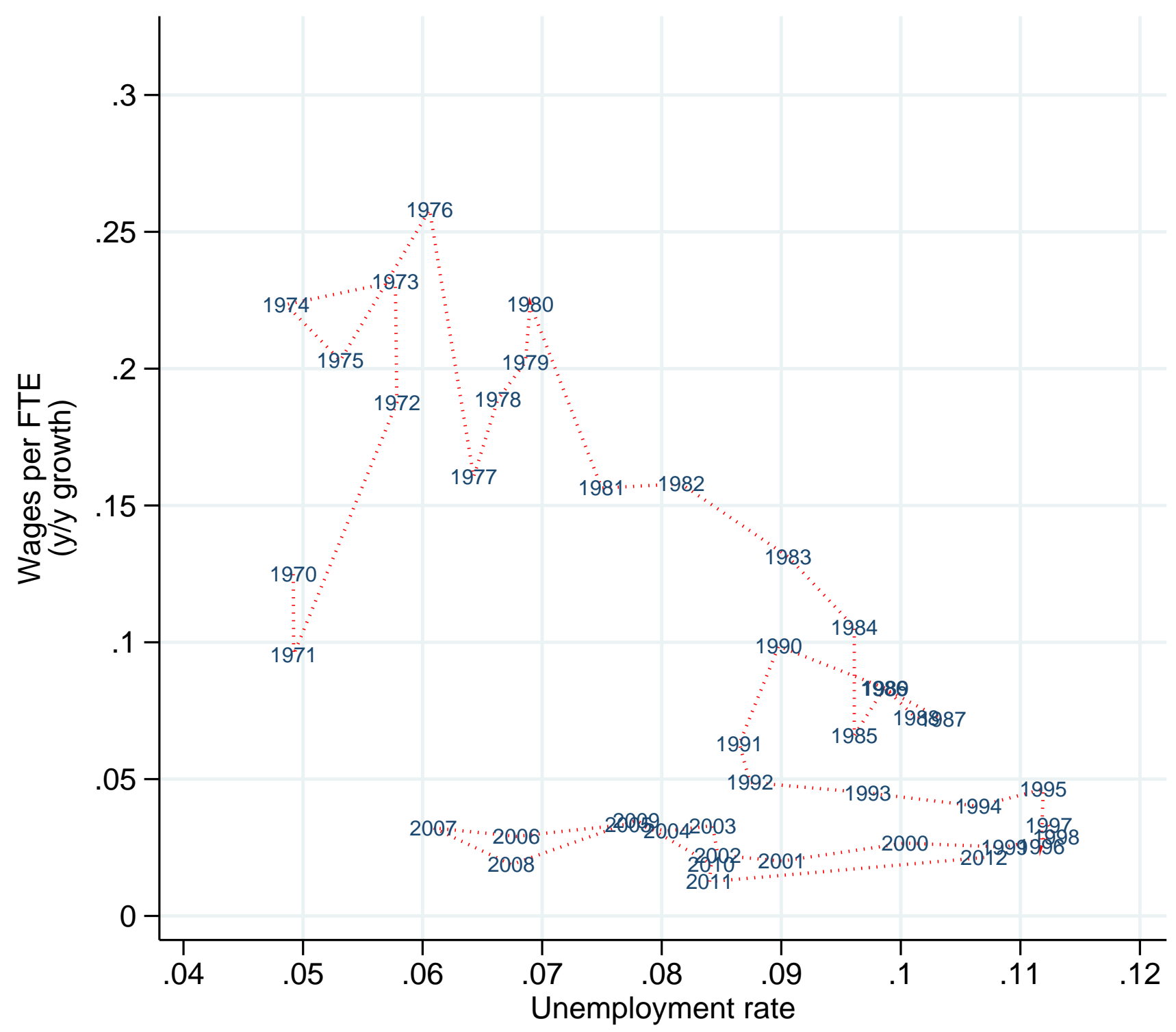


Figure 2: Wage and price inflation and the unemployment rate.

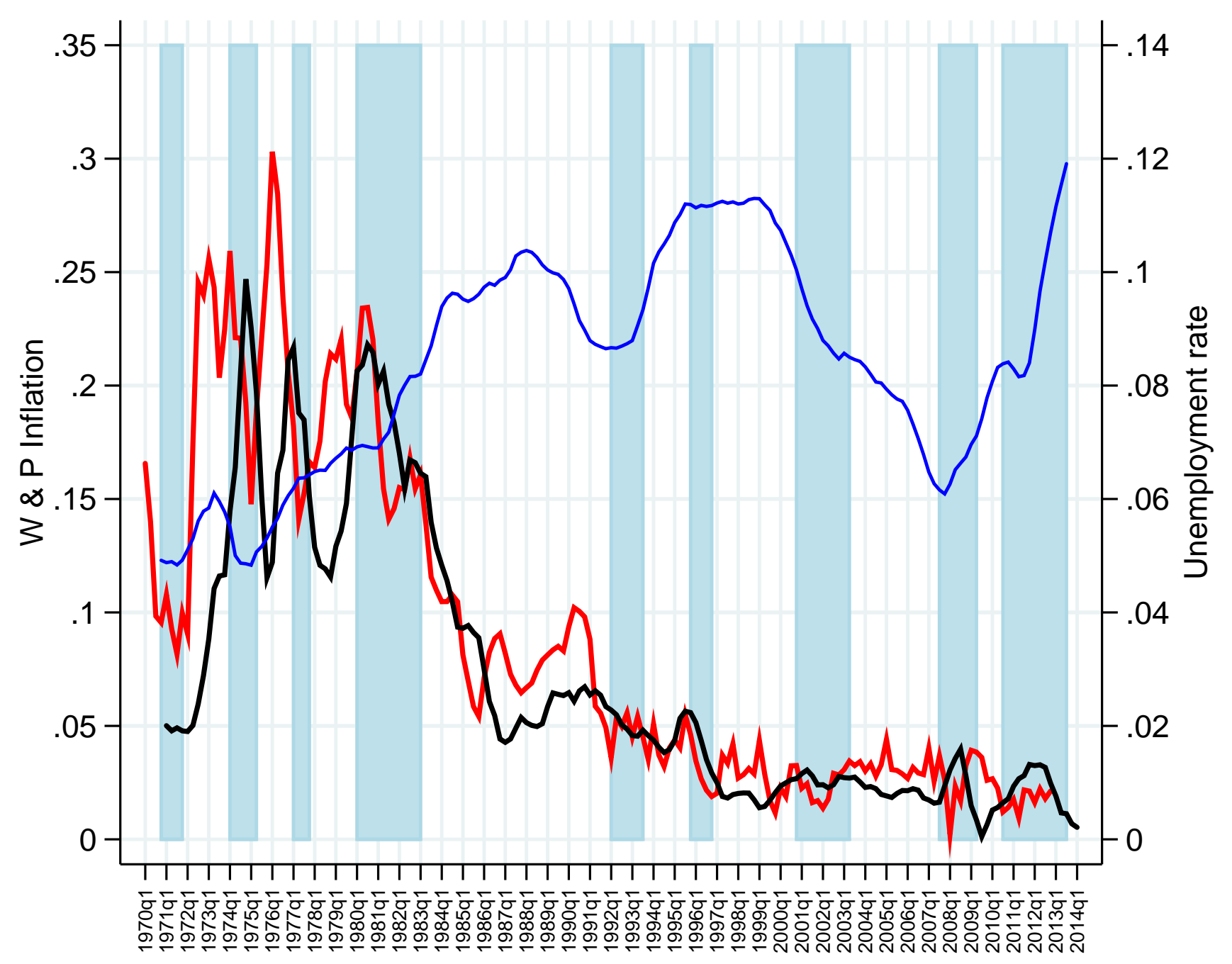

- Wage inflation - Price inflation - Unemployment rate 
Figure 3: The Italian wage Phillips curve since 2000.

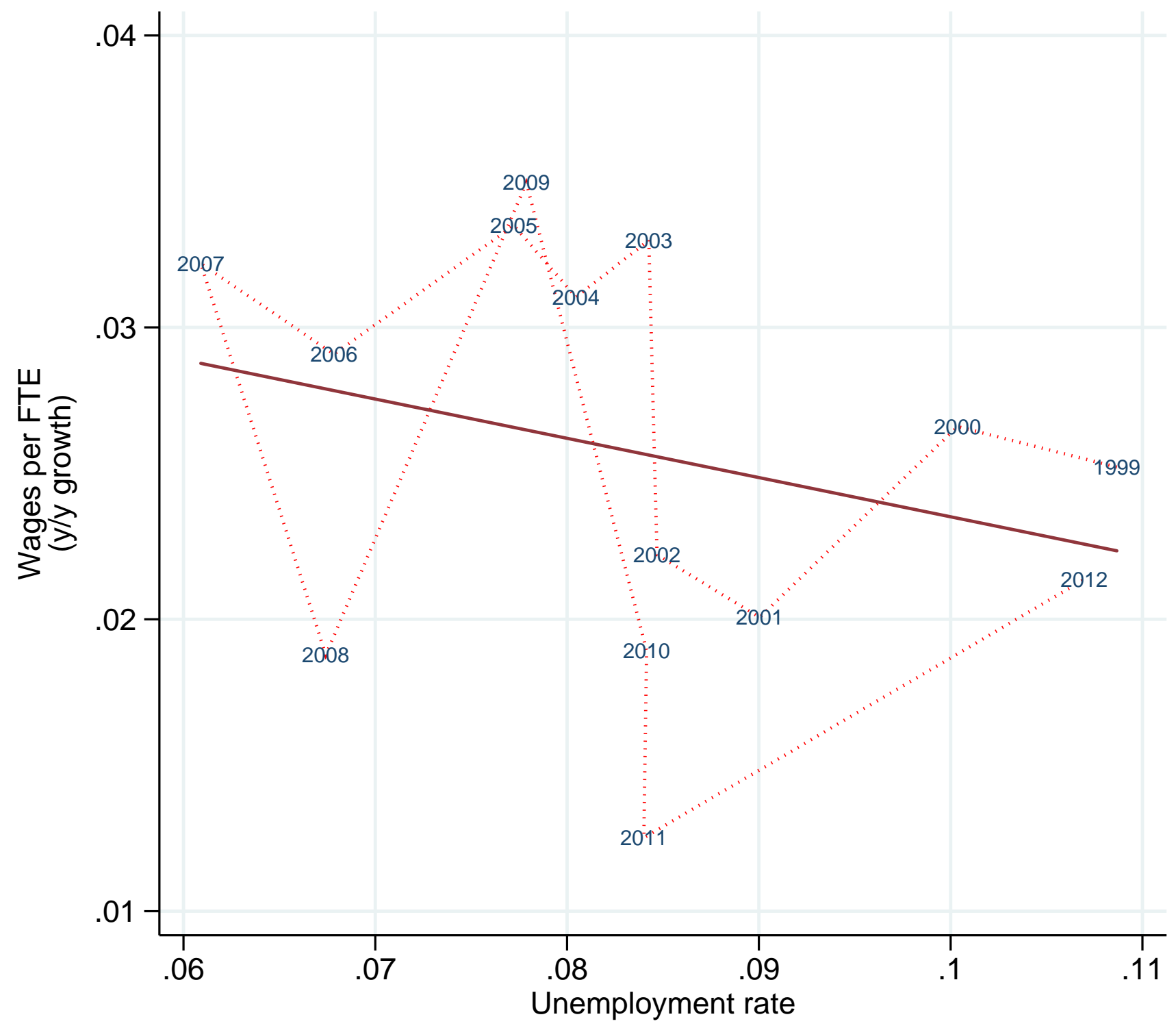


Figure 4: Examples of contract renewals.
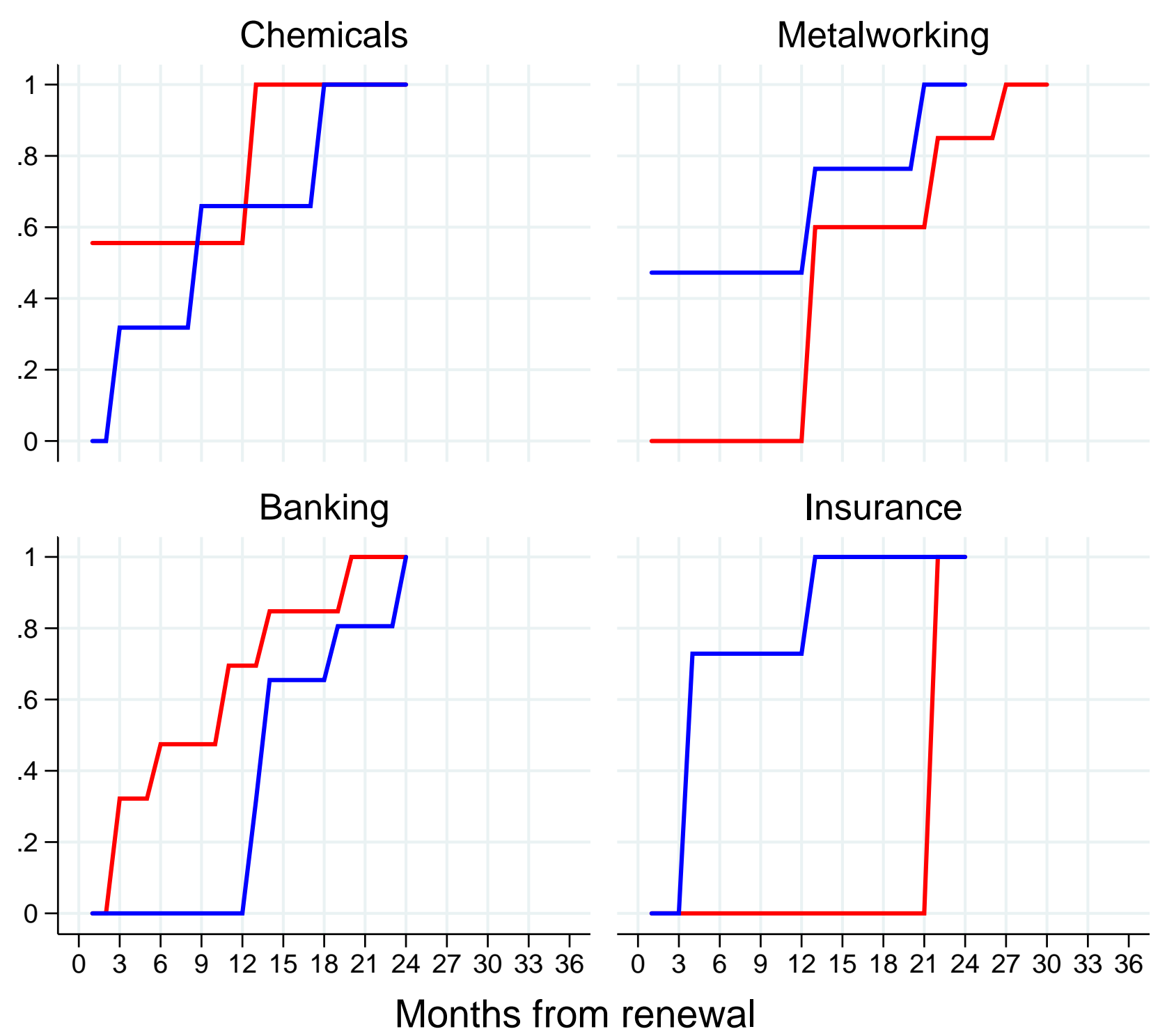

1 
Figure 5: Negotiated wages, NAs wages and unemployment.

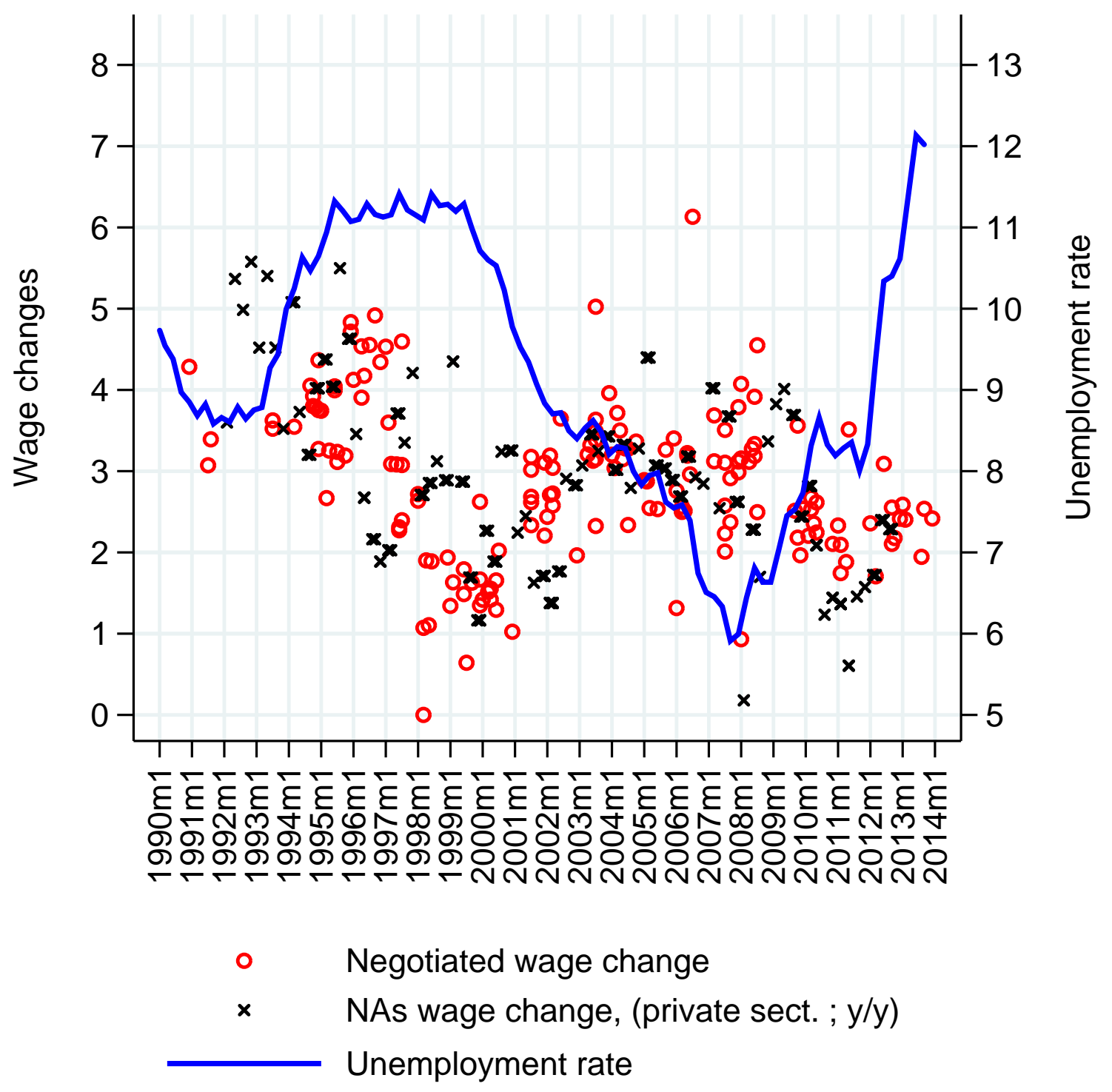


Figure 6: Negotiated wage change and unemployment.
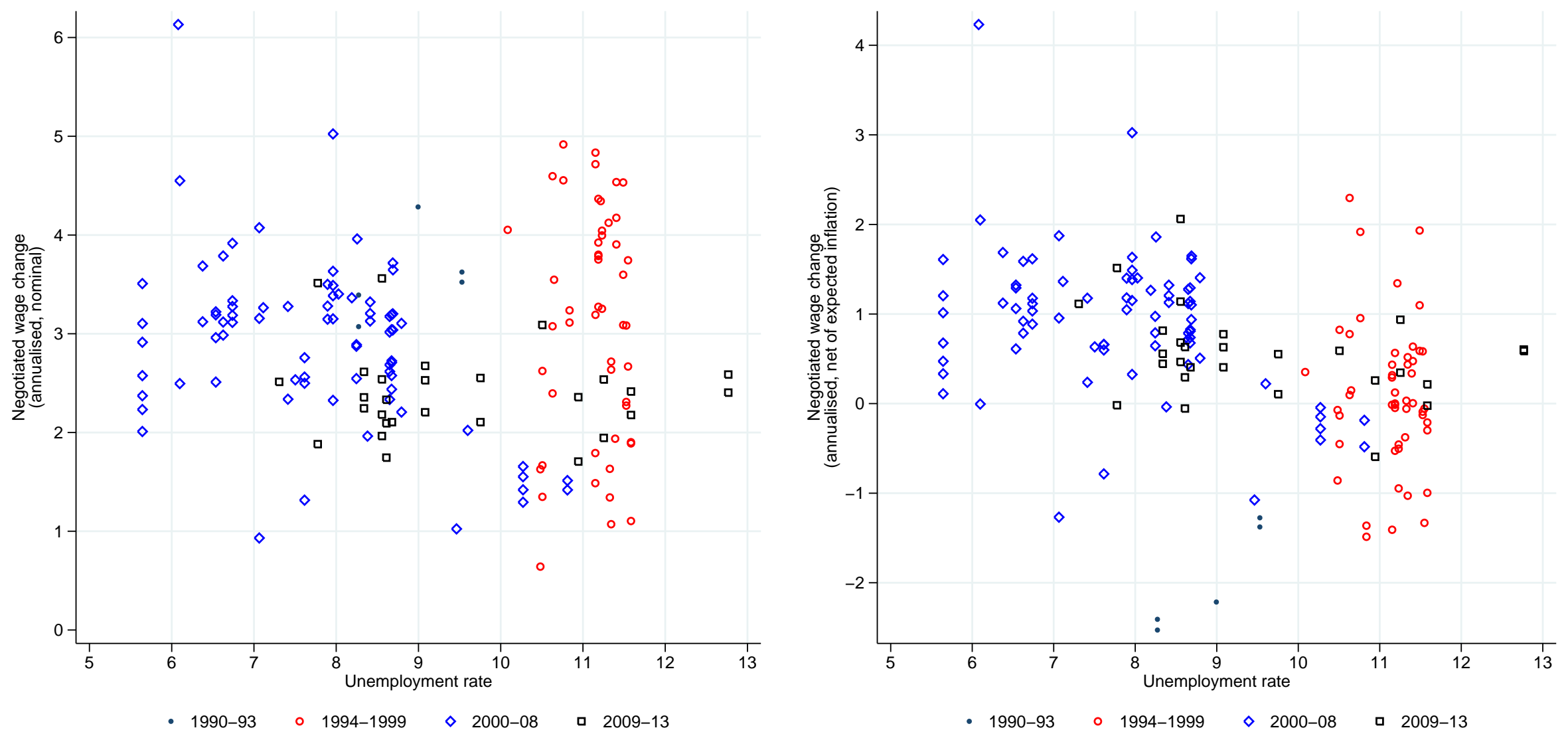
Figure 7: Additional firm-level pay rises.

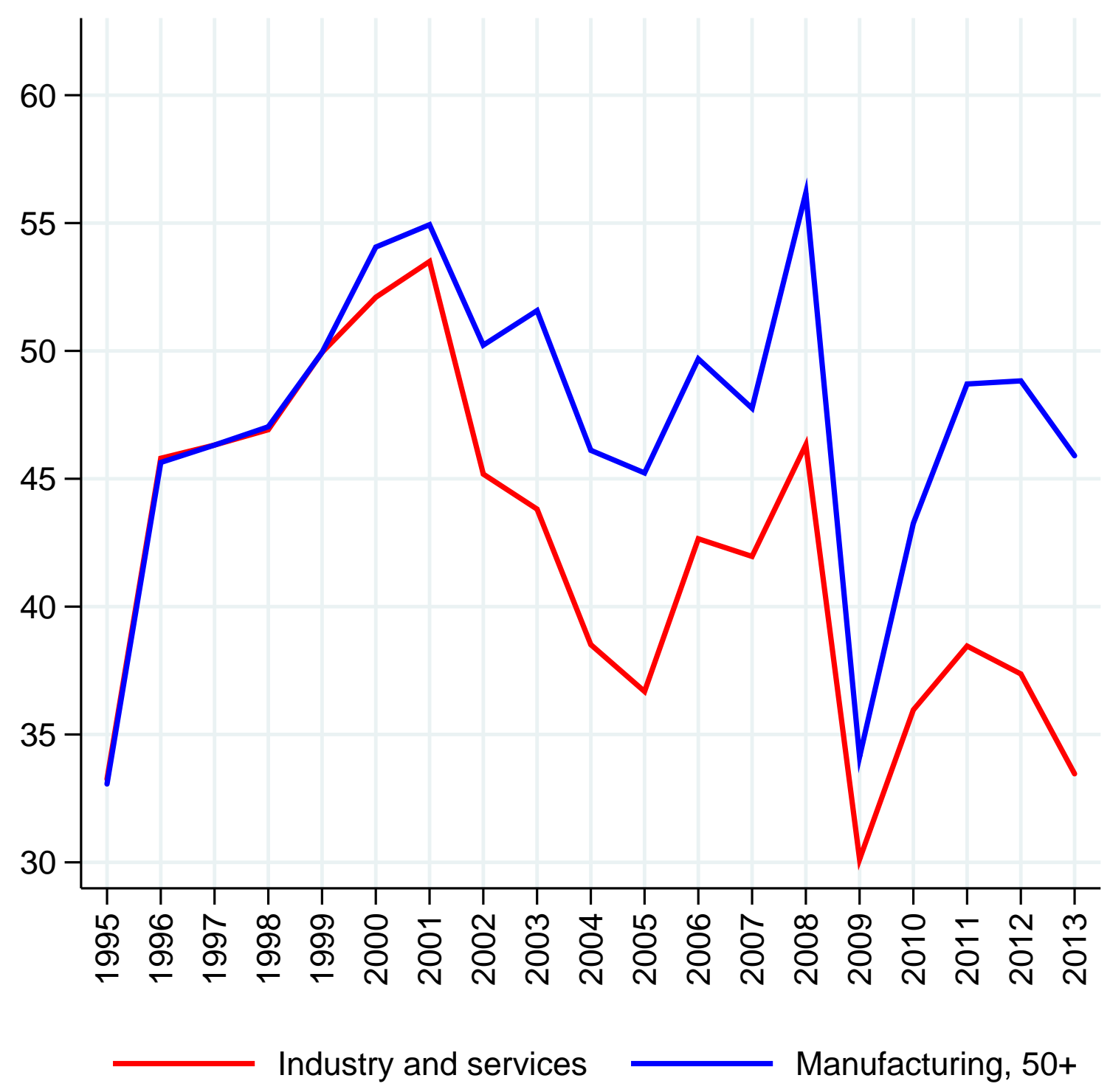


Figure 8: Probability of firm-set wage rises and unemployment.

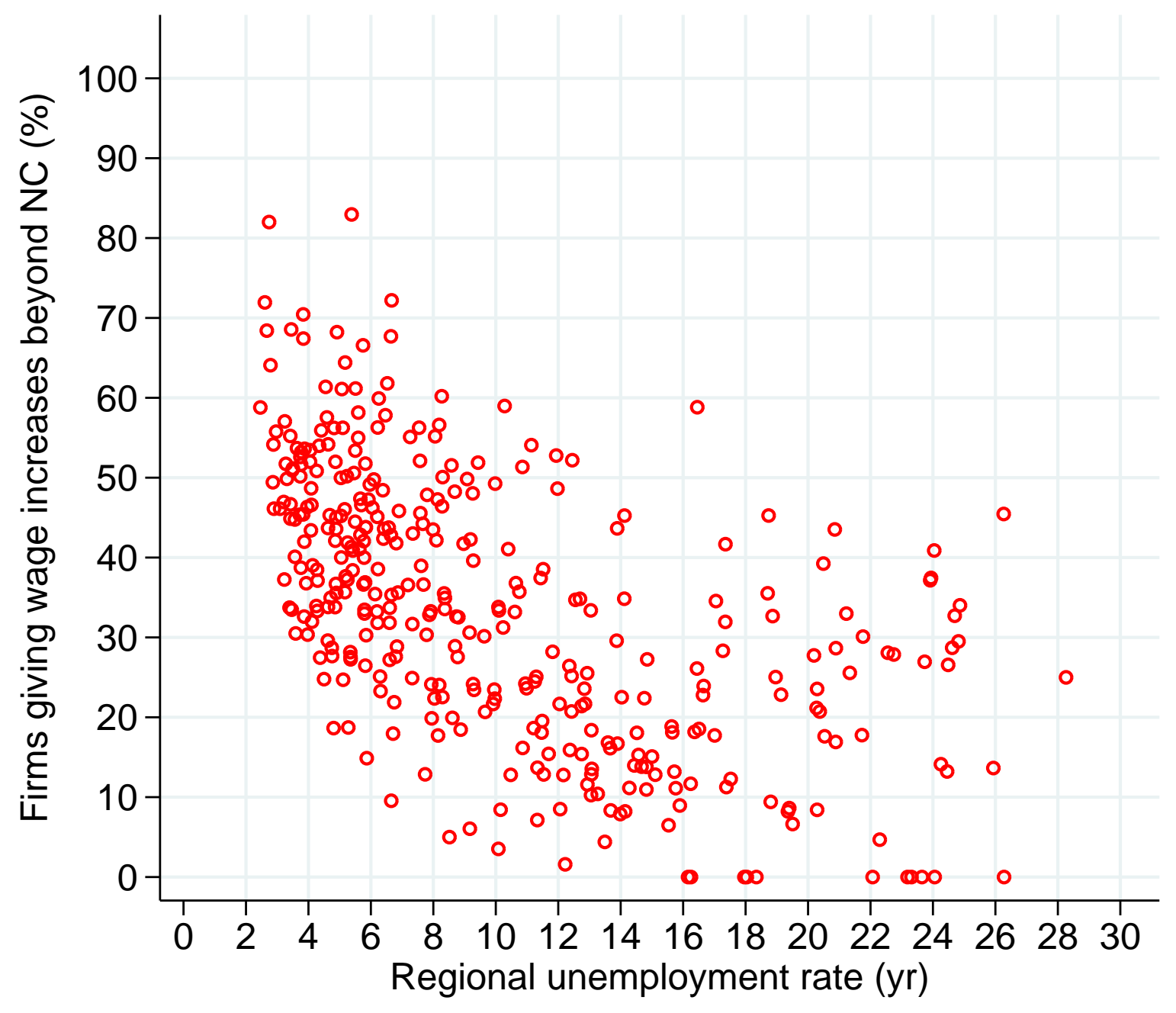


Figure 9: Incidence of firm-level wage items Phillips curve.

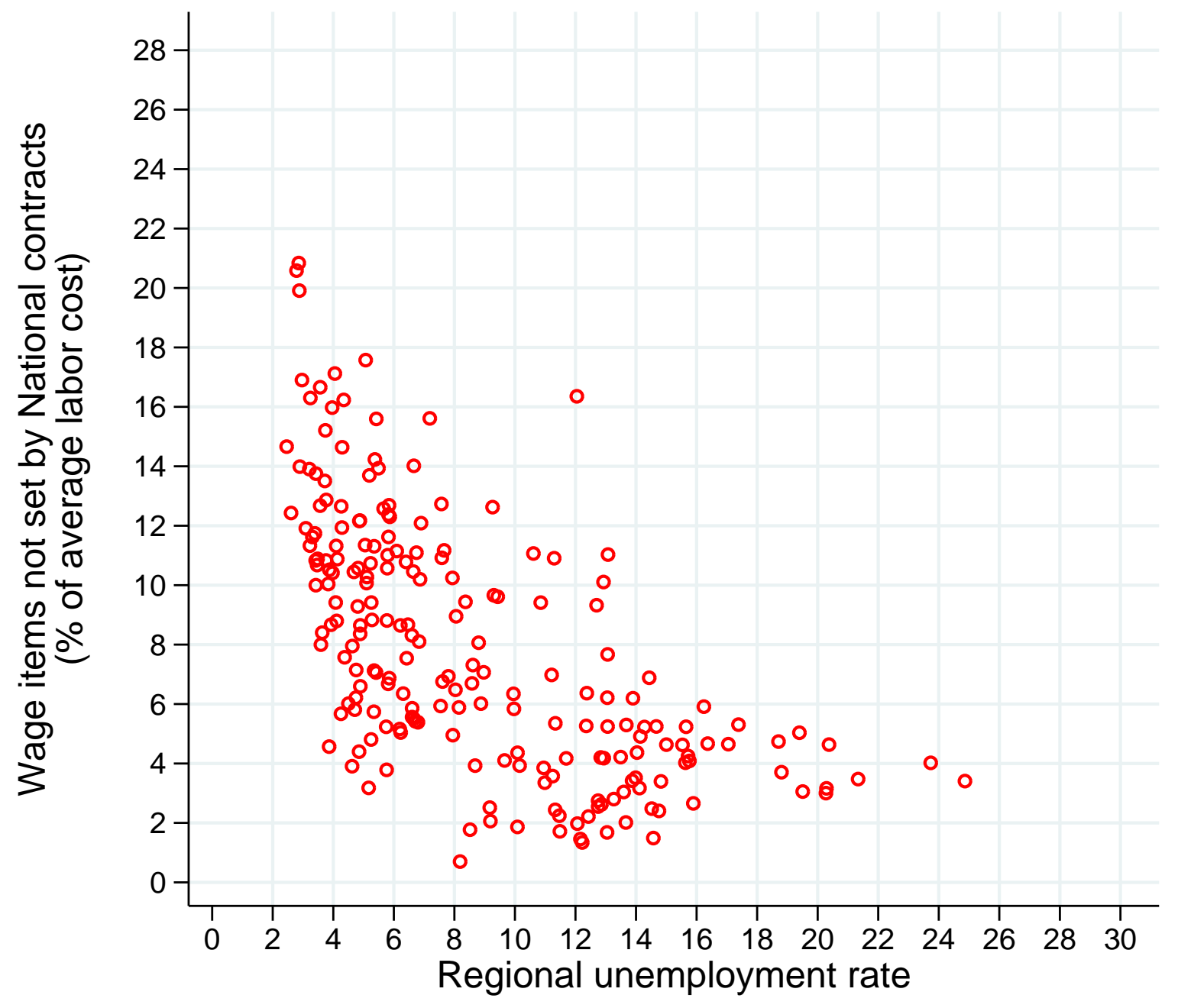


Table 1: Estimated wage inflation equations.

\begin{tabular}{lcccccccccccc}
\hline \hline & $(1)$ & $(2)$ & $(3)$ & $(4)$ & $(5)$ & $(6)$ & $(7)$ & $(8)$ & $(9)$ & $(10)$ & $(11)$ \\
& & & & & & & & & & & \\
$U R_{t}$ & -2.239 & -1.078 & -2.390 & -0.870 & -0.105 & -0.090 & -0.057 & -0.051 & -0.051 & -0.031 & 0.027 \\
& $(0.231)$ & $(0.199)$ & $(0.256)$ & $(0.217)$ & $(0.098)$ & $(0.073)$ & $(0.073)$ & $(0.060)$ & $(0.077)$ & $(0.066)$ & $(0.074)$ \\
$\pi_{t}$ & & 0.854 & & 0.888 & 0.886 & -0.589 & & -0.498 & & -0.547 & -0.972 \\
& & $(0.056)$ & & $(0.056)$ & $(0.138)$ & $(0.224)$ & & $(0.138)$ & & $(0.140)$ & $(0.183)$ \\
$\mathrm{E}\left(\Delta U_{t+4}\right)$ & & & 0.184 & 0.001 & 0.009 & -0.022 & & & -0.004 & -0.011 & -0.017 \\
& & & $(0.030)$ & $(0.020)$ & $(0.009)$ & $(0.009)$ & & & $(0.009)$ & $(0.009)$ & $(0.009)$ \\
$\mathrm{E}\left(\pi_{t+4}\right)$ & & & & & & 1.821 & & & & & 1.783 \\
& & & & & & $(0.296)$ & & & & & $(0.606)$
\end{tabular}

$\begin{array}{llllllllllll}\text { Obs. } & 171 & 167 & 159 & 159 & 93 & 93 & 59 & 59 & 59 & 59 & 59\end{array}$

Robust standard errors in parentheses. Dependent variable: percentage change of nominal wage per FTE between quarters $t$ and $t+4 ; \pi_{t}$ : consumer price percentage growth between quarters $t-4$ and $t ; E\left(\Delta U_{t+4}\right)$ : percentage of households expecting an increase in unemployment over the next year (Isae/Istat monthly household surveys); $E\left(\pi_{t+4}\right)$ : expected inflation over next year (Consensus forecast).

Samples: cols. (1)-(4): 1970-2012; cols. (5)-(6): 1989-2012; cols. (7)-(11): 1998-2012. 
Table 2: Determinants of centrally bargained wage changes

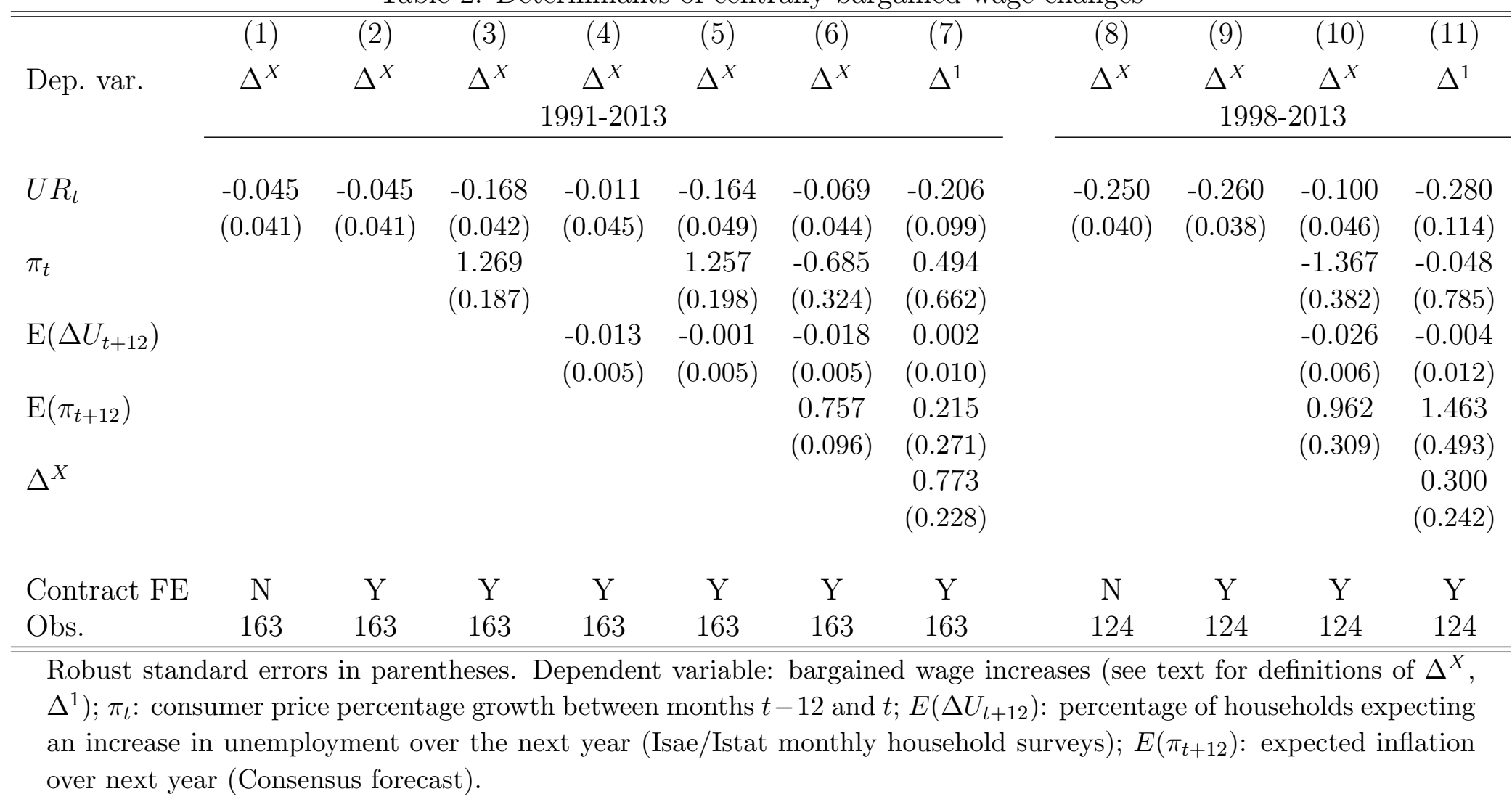


Table 3: Probability of firm-level additional pay rises.

\begin{tabular}{|c|c|c|c|c|c|c|c|}
\hline & $(1)$ & $(2)$ & $(3)$ & $(4)$ & $(5)$ & $(6)$ & $(7)$ \\
\hline$U R_{\text {reg }}$ & $\begin{array}{l}-2.1^{* * *} \\
(0.056)\end{array}$ & & & & & & \\
\hline$U R_{r e g}<=12 m$ & & $\begin{array}{l}-4.8^{* * *} \\
(0.202)\end{array}$ & $\begin{array}{r}-3.1^{* * *} \\
(0.198)\end{array}$ & $\begin{array}{c}-1.2^{* * *} \\
(0.447)\end{array}$ & $\begin{array}{r}-1.3^{* * *} \\
(0.444)\end{array}$ & $\begin{array}{c}-1.5^{* * *} \\
(0.558)\end{array}$ & $\begin{array}{r}-2.1^{* * *} \\
(0.745)\end{array}$ \\
\hline$U R_{\text {reg }}>12 m$ & & $\begin{array}{c}-0.780^{* * *} \\
(0.106)\end{array}$ & $\begin{array}{c}0.584^{* * *} \\
(0.144)\end{array}$ & $\begin{array}{c}0.187 \\
(0.164)\end{array}$ & $\begin{array}{c}0.229 \\
(0.163)\end{array}$ & $\begin{array}{l}-0.335 \\
(0.220)\end{array}$ & $\begin{array}{c}-728 \\
(0.385)\end{array}$ \\
\hline \multicolumn{8}{|c|}{ Expected profits (ref. Break-even) } \\
\hline Strongly negative & & & & & $\begin{array}{c}1.9^{* *} \\
(0.977)\end{array}$ & $\begin{array}{c}2.1^{* *} \\
(0.975)\end{array}$ & $\begin{array}{c}1.6 \\
(1.006)\end{array}$ \\
\hline Weakly negative & & & & & $\begin{array}{c}0.8 \\
(0.764)\end{array}$ & $\begin{array}{c}0.9 \\
(0.763)\end{array}$ & $\begin{array}{l}0.258 \\
(0.784)\end{array}$ \\
\hline Weakly positive & & & & & $\begin{array}{l}9.4^{* * *} \\
(0.603)\end{array}$ & $\begin{array}{l}9.3^{* * *} \\
(0.602)\end{array}$ & $\begin{array}{l}8.8^{* * *} \\
(0.618)\end{array}$ \\
\hline Strongly positive & & & & & $\begin{array}{c}23.0^{* * *} \\
(0.789)\end{array}$ & $\begin{array}{c}22.7^{* * *} \\
(0.789)\end{array}$ & $\begin{array}{r}23.2^{* * *} \\
(0.813)\end{array}$ \\
\hline \multicolumn{8}{|c|}{ Order books developments (ref. Stationary) } \\
\hline Strong decline & & & & & $\begin{array}{l}-3.1^{* * *} \\
(0.749)\end{array}$ & $\begin{array}{c}-3.1^{* * *} \\
(0.748)\end{array}$ & $\begin{array}{r}-2.4^{* * *} \\
(0.768)\end{array}$ \\
\hline Weak decline & & & & & $\begin{array}{c}0.2 \\
(0.609)\end{array}$ & $\begin{array}{c}0.1 \\
(0.608)\end{array}$ & $\begin{array}{l}-0.275 \\
(0.627)\end{array}$ \\
\hline Weak increase & & & & & $\begin{array}{l}1.6^{* * *} \\
(0.544)\end{array}$ & $\begin{array}{l}1.6^{* * *} \\
(0.543)\end{array}$ & $\begin{array}{l}2.0^{* * *} \\
(0.563)\end{array}$ \\
\hline Strong increase & & & & & $\begin{array}{l}5.6^{* * *} \\
(0.745)\end{array}$ & $\begin{array}{l}5.9 * * * \\
(0.745)\end{array}$ & $\begin{array}{l}5.1^{* * *} \\
(0.768)\end{array}$ \\
\hline Obs. & 52484 & 52484 & 52484 & 52484 & 51802 & 51802 & 51802 \\
\hline
\end{tabular}

Dependent variable: 100 if pay rises on top of NC have been paid, 0 otherwise. Weighted LS; weights are number of employees. Columns (3)-(6) include FE for (size-sector-area); columns (4)-(6) include year dummies; column (6) includes region dummies; column (7) includes (sizesector-area)-specific year dummies and region dummies. 
Table 4: Incidence of firm-level wage items.

\begin{tabular}{|c|c|c|c|c|c|c|c|}
\hline & (1) & 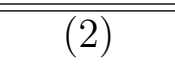 & 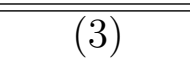 & $\overline{(4)}$ & 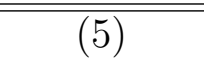 & 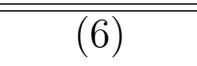 & 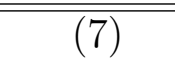 \\
\hline$U R(\%)$ & $\begin{array}{c}-0.70 * * * \\
(0.014)\end{array}$ & $\begin{array}{c}-0.27^{* * *} \\
(0.041)\end{array}$ & $\begin{array}{c}-0.35^{* * *} \\
(0.050)\end{array}$ & & & & \\
\hline$U R \leq 12 m(\%)$ & & & & $\begin{array}{c}-0.93^{* * *} \\
(0.178)\end{array}$ & $\begin{array}{c}-1.08^{* * *} \\
(0.175)\end{array}$ & $\begin{array}{c}-0.82^{* * *} \\
(0.247)\end{array}$ & $\begin{array}{c}5.56^{* * * *} \\
(0.748)\end{array}$ \\
\hline$U R>12 m(\%)$ & & & & $\begin{array}{c}-0.16^{* *} \\
(0.075)\end{array}$ & $\begin{array}{c}-0.15^{* *} \\
(0.074)\end{array}$ & $\begin{array}{c}0.17 \\
(0.111)\end{array}$ & $\begin{array}{l}1.8^{* * *} \\
(0.315)\end{array}$ \\
\hline$\Delta$ sales $(\%)$ & & & $\begin{array}{c}0.012^{* * *} \\
(0.004)\end{array}$ & $\begin{array}{c}0.012^{* * *} \\
(0.003)\end{array}$ & $\begin{array}{c}0.014^{* * *} \\
(0.003)\end{array}$ & $\begin{array}{c}0.014^{* * *} \\
(0.004)\end{array}$ & $\begin{array}{c}-0.028^{* *} \\
(0.015)\end{array}$ \\
\hline$\Delta$ Employees $(\%)$ & & & $\begin{array}{l}0.008^{*} \\
(0.004)\end{array}$ & $\begin{array}{l}0.007^{*} \\
(0.004)\end{array}$ & $\begin{array}{c}0.003 \\
(0.004)\end{array}$ & $\begin{array}{c}0.007 \\
(0.006)\end{array}$ & $\begin{array}{l}-0.017 \\
(0.016)\end{array}$ \\
\hline L Turnover & & & $\begin{array}{l}-0.096 \\
(0.070)\end{array}$ & $\begin{array}{l}-0.097 \\
(0.070)\end{array}$ & $\begin{array}{c}-0.223^{* * * *} \\
(0.068)\end{array}$ & $\begin{array}{c}-0.405^{* * *} \\
(0.084)\end{array}$ & $\begin{array}{c}-0.678^{* * *} \\
(0.291)\end{array}$ \\
\hline$\%$ Blue-collar & & & $\begin{array}{c}-0.061^{* * *} \\
(0.003)\end{array}$ & $\begin{array}{c}-0.060^{* * *} \\
(0.003)\end{array}$ & $\begin{array}{c}-0.094^{* * *} \\
(0.003)\end{array}$ & $\begin{array}{c}-0.091^{* * *} \\
(0.003)\end{array}$ & $\begin{array}{c}0.232^{* * *} \\
(0.001)\end{array}$ \\
\hline$\%$ Extra-hrs & & & $\begin{array}{c}0.182^{* * *} \\
(0.016)\end{array}$ & $\begin{array}{c}0.185^{* * *} \\
(0.016)\end{array}$ & $\begin{array}{c}0.285^{* * *} \\
(0.016)\end{array}$ & $\begin{array}{c}0.273^{* * *} \\
(0.020)\end{array}$ & $\begin{array}{c}-0.789^{* * *} \\
(0.069)\end{array}$ \\
\hline (log) NB wage & & & & & $\begin{array}{c}-10.5^{* * *} \\
(0.251)\end{array}$ & $\begin{array}{c}-12.1^{* * *} \\
(0.327)\end{array}$ & $\begin{array}{c}19.2^{* * *} \\
(1.072)\end{array}$ \\
\hline Obs. & 30916 & 30916 & 28187 & 28187 & 27279 & 18216 & 27279 \\
\hline
\end{tabular}

$(* * *) \mathrm{p}<0.0 \overline{1,(* *) \mathrm{p}<0.05,(*) \mathrm{p}<0.1}$

Dependent variables: percentage of average labour cost not determined by National labor contracts (cols. 1 to 6 ); dummy equal 100 if firm reports zero weight of firm-set wage items (col. 7). Weighted LS; weights are number of firms. Columns (2)-(7) also include year-specific dummies for area-size-sector cells. 